\title{
Tüketicilerin Mağaza Atmosferine Verdikleri Önem
}

\author{
Yelda Ülker a, b
}

Özet

Günümüzde satın alma noktası iletişimi çalışmaları aracılığıyla markalar, tüketicinin satın alma kararı vermesine çalışmaktadır. Bu bağlamda satın alma noktası iletişiminin unsurlarından olan mağaza atmosferi, markaların tüketicilerle iletişim kurmasında önemlidir. Bu sebeple markalar, mağaza atmosferini oluştururken hedef kitlesinin yaş, cinsiyet, gelir durumu gibi demografik etkenlerini, iyice araştırılmalı ve bu değişkenleri dikkate alarak mağazalarını dizayn etmelidir. Günümüzde kozmetik pazarı hızla büyümektedir. $\mathrm{Bu}$ araştırmada tüketicilerin kozmetik mağazalarının atmosferine verdikleri önem irdelenmiştir. Tüketicilerin demografik değişkenlikleri (yaş, cinsiyet, medeni durum vb.) ile mağaza atmosferine verdikleri öneme yönelik puanları arasındaki farklılığın belirlenmesi araştırmanın temel amacıdır. Bu bağlamda, araştırmada 320 katılımcıya yüz yüze anket uygulanmıştır. Anova yöntemi ile elde edilen verilere göre, katılımcıların bazı demografik özellikleri ile mağaza atmosferine verdikleri önem puanları arasında fark bulunmaktadır.
Anahtar Kelimeler

Satın alma noktası iletişimi

Mağaza atmosferi

Tüketici davranışları

İletişim

Makale Hakkında

Geliş Tarihi: 10.02 .2019

Kabul Tarihi: 20.11.2019

Doi: $10.18026 /$ cbayarsos.525180

\section{Importance of Store Atmosphere for the Consumers}

\begin{abstract}
Today, through point-of-purchase communication efforts, brands are trying to make a consumer's decision to buy. In this context, the store atmosphere, which is one of the elements of point-of-sale communication, is important for brands to communicate with consumers. For this reason, brands, while creating a store atmosphere, demographic factors such as age, gender, income status of the target audience should be thoroughly investigated and designed their stores by considering these variables. Today, the cosmetics market is growing rapidly. In this research, the importance of consumers to the atmosphere of cosmetics stores was examined. The main purpose of the research is to determine the difference between the demographic variables (age, gender, marital status, etc.) of consumers and their importance points to the store atmosphere. In this context, a face-to-face questionnaire was applied to 320 participants. According to the data obtained by the Anova method, there is a difference between some demographic characteristics of the participants and the importance of store atmosphere for them.
\end{abstract}

Keywords

Point of purchase communication

Store atmosphere

Consumer behavior

Communication

About Article

Received: 10.02.2019

Accepted: 20.11.2019

Doi: 10.18026/cbayarsos.525180

a İletişim Yazarı: yeldaulker@hotmail.com

b Arş. Gör., Marmara Üniversitesi/ Göztepe Kampüsü - İST., ORCID: 0000-0001-8105-2686 


\section{Giriş}

Tüketicilerin çoğunluğunun alışveriş kararını satın alma noktalarında gerçekleştirdiğini bilen markalar, tüketicinin satın alma kararı almasını sağlamak için satın alma noktası iletişimi çalışmalarına öncelik vermektedir. Bu sebeple, markalar satın alma noktası iletişiminin parçaları olan mağaza atmosferi, mağaza içi reklam, mağaza düzeni gibi unsurları kullanarak tüketici ile iletişim kurmaya çalışmaktadır. Markalar özellikle satın alma noktası iletişimin önemli bir ayağı olan mağaza atmosferine öncelik vermektedir. Bu bağlamda markalar, koku, renk, müzik, aydınlatma, çalışanların görünüşleri gibi unsurları kullanarak mağaza atmosferleri yaratmakta ve tüketicinin zihninde imaj oluşturmaktadır. İmaj yaratmak, o imajı sürdürmek, müşterilerinin dikkatini çekmek ve rakiplerden ayrışmayı sağlamak için sıklıkla kullanılan mağaza atmosferini oluştururken dikkat edilmesi gereken hedef kitlenin doğru seçilmesidir. Diğer bir deyişle tüketicilerin yaş, cinsiyet, gelir, medeni durum gibi demografik etkenler, mağaza atmosferini oluşturmadan önce iyice araştırılmalı ve tüketicideki bu değişkenler dikkate alınarak hazırlanmalıdır. Bu bağlamda, markalar hedef kitlelerinde oluşturmak istedikleri imaja ve mağaza atmosferine göre renk, koku, tat, müzik gibi unsurlara karar verilmelidir.

$\mathrm{Bu}$ araştırmada da tüketicilerin kozmetik mağazalarının atmosferine verdikleri önem incelenmiştir. Diğer bir deyişle, tüketicilerin demografik değişkenlikleri (yaş, cinsiyet, medeni durum vb.) ile mağaza atmosferine verdikleri öneme yönelik puanları arasındaki farklılığın belirlenmesi araştırmanın temel amacıdır. Araştırma zaman ve mali kısıtlarından dolayı anket çalışması için Nişantaşı bölgesi tercih edilmiştir. Bu bağlamda en fazla mağaza sayısına sahip cadde olan Nişantaşı bölgesinde tüketicinin cinsiyeti, yaşı, eğitim ve medeni durumu gibi demografik özellikleri ile mağaza atmosferine verdikleri önem arasında fark olup olmadığı irdelenmek için 320 kişiye yüz yüze anket uygulanmıştır.

\section{Satın Alma Noktası İletişimi Kavramı (POP)}

Satın alma davranışları kesin planlanmış, genel planlanmış ve planlanmamış olarak gerçekleşmektedir. Tüketicinin mağazaya girmeden önce alacağ1 markaya karar vermesi kesin planlanmış satın alma davranışı iken, sadece belirli bir ürüne karar vermesi ise genel olarak planlanmış satın alma davranışıdır. Tüketicinin önceden karar vermeyip gerçekleştirdiği alımlar ise planlanmadan gerçekleşen satın alma davranışı içine girmektedir. Bu bağlamda satın alma noktalarında gerçekleştirilen çalışmalar aracılığıyla tüketicinin özellikle planlanmayan satın alma davranışı sergilemesine çalışılmaktadır. Diğer bir deyişle, çoğu tüketici satın alma kararını, satın alma noktalarında gerçekleştirmektedir. Bu bağlamda, mağaza imajı, ambalajlama, mağaza organizasyonu, ürün sunumu, mağaza attmosferi bileşimlerinden oluşan satın alma noktası iletişiminin, tüketicinin satın alma kararında etkili bir araç olduğu söylenebilir (Pelsmacker, Gueuns ve Bergh, 2001). Tüketicinin satın alma kararını yönlendirme amacıyla satın alma noktalarında uygulanan koku, müzik, fiyatlandırma etiketi gibi çeşitli uygulamalar aracılığıyla markalar tüketiciyi etkilemekte ve satın alma noktası iletişimini sağlamaktadır (Tosun, 2017: 423). Diğer bir deyişle, tüketiciler alışverişlerinin büyük bir kısmını satın alma noktasında bulunan unsurlar sayesinde aldıkları ani kararlar ile gerçekleştirmektedirler. Yapılan araştırmalara göre özellikle genç, yüksek gelire sahip, geniş ve çocuklu aileler planlamadan yaptıkları satın almaların çoğunu 
mağazalarda gerçekleştirmektedir (Pelsmacker, Gueuns ve Bergh, 2001: 350). Bu sebeple mağazanın atmosferinin tüketicinin ruh hâlini, davranışlarını ve satın alma kararlarını etkilediği söylenebilir (Bayraktar, 2011: 7).

Satın alma noktası iletişiminin birer parçası olan mağaza içindeki koku, müzik, raf, ürünlerin ambalajı gibi unsurlar (Pelsmacker, Gueuns ve Bergh, 2001: 352) sayesinde tüketici mağaza ve mağaza içindeki ürünler hakkında bilgi edinmektedir (Tosun, 2017: 424). Özellikle daha önceden satın alma kararı almamış olan tüketiciler satın alma noktasında uygulanan iletişim çalışmaları ile satın alma davranışı gösterebilmektedir (Pelsmacker, Gueuns ve Bergh, 2001: 349). Bu bağlamda markalar; mağaza atmosferi, imajı, dizaynı, mağazadaki ürünlerin ambalajları ve sunuş biçimleri gibi unsurlara dikkat etmektedir. (Tosun, 2017: 425-426). Bunların yanı sıra ürün çeşitleri, nitelikleri, fiyatları gibi ürünle ilgili konular tüketicinin zihninde imaj oluşturmaktadır. Bu bağlamda tüm bu unsurlar satın alma noktası iletişim çalışmalarının kapsamı içinde yer almaktadır (Rosenberg, 1995). Tüketicinin zihninde rakiplerden farklı bir konumda olmak isteyen markalar, satın alma noktası iletişime yönlenmekte ve tüketicinin zihninde güçlü bir mağaza imajı oluşturmaya çalışmaktadırlar (Yeniçeri, 2005: 40). Bu bağlamda mağaza imajı ile ilgili çalışmalar yapan Martineau (1958: 49), mağazanın imajının, mağazanın kişiliği olduğunu söylerken, Turley ve Chebat (2002: 132) ise mağaza imajı için tüketicide bırakılan izlenim tanımında bulunmuştur. Bir diğer satın alma noktası iletişim çalışmaları unsuru ise mağaza organizasyonudur; mağazanın toplam alanının belirlenerek, belli planlar çerçevesinde mağazanın kısımlara ayrılıp, en uygun şekilde ürün yerleştirmenin yapılmasıdır (Tosun, 2017: 428). Mağazanın organizasyonu yapılırken; tüketicilerin rahat hareket edebilmeleri, ürünlerin en doğru şekilde sergilenmesi gibi unsurlar dikkate alınmaktadır. Özellikle ürün yerleşimi yapılırken ürünlerin birlikteyken uyumlu olması ve böylece satın alma davranışı sağlaması önemlidir (Inman ve Winer: 1998). Bu bağlamda satın alma noktası iletişiminde ürünün sunumu da dikkat edilmesi gereken unsurlardandır. Mağazada sergilenecek ürünlerinin diziliş sıralarının nasıl oluşturulacağı, rafların pozisyonu ve tanzimi dikkatle oluşturulmuş stratejilerin sonucudur. Bu sebeple ürünün tüketim hızı, pazar ve perakende payı raf alanlarının belirlenmesinde önemli kriterlerdir (Mulhern, 1997: 103-124). Ürünün doğru bir strateji ile sunumunun tasarlanmasının yanı sıra ambalajı da iyi bir satın alma noktası iletişiminin sağlanmasında önemlidir. Mağazada sergilenen ürünler, ambalaj1 yani şekli, rengi, kullanılan materyalleri ile müşterilerin dikkatini çekmektedir (Tosun, 2017: 431). Satın alma noktası iletişimi kanalı olan bir diğer unsur ise mağaza atmosferidir.

\section{Satın Alma Noktası iletişimi Kanalı Olarak Mağaza Atmosferi}

Markalar tüketicinin zihninde istedikleri imajı yaratmak, sürdürmek, müşterilerinin dikkatini çekmek ve rakiplerden ayrışmayı sağlamak için mağaza atmosferine önem vermektedir (Berman ve Evans, 1992). Diğer bir deyişle mağaza atmosferi için; koku, müzik, aydınlatma, çalışanların veya müşterilerin görünüşleri, kullanılan renkler gibi uyaranların birleşerek oluşturduğu ortam denilebilir (Childers, Carr, Peck ve Carson, 2001: 513). Bu bağlamda mağaza atmosferinin iç ve dış unsurların bileşimiyle oluştuğu görülmektedir (Arslan, 2016: 119). Mağaza atmosferlerinin oluşumunda hedef kitlenin özellikleri önemlidir. Diğer bir deyişle tüketicilerin yaş, cinsiyet, ekonomik durum gibi demografik etkenler, mağaza atmosferini oluşturmada dikkat edilmesi gereken unsurlardandır (Akyüz, 2015). Örneğin, 
Fettahlığlu (2014)'nun yapmış olduğu bir araştırmaya göre mağaza içindeki müziğe olan tutumları tüketicinin cinsiyetine göre farklılıklar göstermektedir. Araştırmaya göre, erkek tüketiciler mağaza içi müziğe kadınlara göre daha hassastır. Bu bağlamda, marka mağaza müziğini seçerken hedef kitlesinin cinsiyeti gibi demografik özelliklere de dikkat etmelidir. Mağaza atmosferi unsurlarından biri olan müziğin mağaza imajını güçlendirdiği, tüketiciyi mağazaya çektiği ve satın almayı arttırdığı düşünüldügünde (Milliman, 1982: 86; Bayçu, 2016: 150; Yalch ve Spangenberg, 2000: 141) hedef kitleye uygun müzik seçmenin önemi anlaşılmaktadır. Tıpkı müzik gibi koku da mağaza atmosferinin önemli bir unsurudur. İnsan davranışında etkili olduğu bilinen koku, en güçlü bellek olarak tanımlanmakta ve insanların karar alma sürecini etkilemektedir (Batı, 2013: 200; Vlahos, 2007). Satın almayı etkileyen bir diğer duyu da dokunma olduğu hâlde pazarlamacılar tarafından yeterince dikkate alınmamaktadır (Arslan, 2011: 62). Hâlbuki tüketiciler bir ürünü satın almadan önce o ürüne dokunmak istemekte ve bu dokunma hissi, o ürünün mağaza atmosferini de etkilemektedir (Kachaganova, 2008: 112). Tüketici de dokunma duyusuna hitap etmenin önemini bilen markalardan biri olan Zippo markası yüzeyini ince metal olarak tasarlamıştır (Batı, 2013: 210). Zippo markasının yüzeyine dokunan tüketici, ürün ile duygusal bir bağ kurmaktadır. Bu sebepledir ki tüketicinin ürün ile temas etmesi, o ürünü satın almasında etkilidir (Odabaşı ve Barış, 2006: 141). Sadece dokunma, duyu, işitme değil tat duyusu da markalar için önemlidir. Yapılan araştırmalar insanlardaki tat duyusunun anne karnından itibaren geliştiğini göstermektedir (Lindstrom, 2012: 27). Bu sebeple özellikle g1da sektöründe yer alan mağazalar için tüketicinin tat duyusuna hitap etmek önemlidir (Küçükköylü, 2010: 34). Fakat tüketicinin tat alma duyusuna hitap etmek sadece gida sektörü için önemli değildir. D\&R, Alkım ve Remzi Kitabevi gibi markalar da mağazalarının belli kısımlarını kafeye çevirerek tüketicinin tat duyusuna seslenmektedir (Altuna, 2015: 90).

Mağaza atmosferi oluşturulurken sadece duyulara seslenilmemektedir. Mağazanın iç ve dış görüntüsü de mağazanın atmosferini oluşturan unsurlar arasındadır. Bu sebeple mağazanın sıcak, soğuk veya havasız olması gibi iç etkenler (Arslan, 2011: 63) ve mağazanın diş düzenlenmesinde kullanılan ışıklandırma, tabela ve vitrin gibi materyaller tüketiciyi mağazaya çekmekte önemlidir (Demirci, 2000: 17). Ayrıca mağazanın konumu da tüketiciyi mağazaya çekmekte önem taşır. Hedef kitlesi için en uygun konuma sahip olan mağazalar, rakiplerine kıyasla avantajlı konumdadırlar (Bayçu, 2016: 40). Bu bağlamda mağazanın konumuna karar verilirken, markanın hedef kitlesinin demografik özellikleri de dikkate alınmalıdır. Akyüz (2015)'ün yapmış olduğu çalışmaya göre, mağazaya ulaşım kolaylığının bulunması kadın tüketiciler için erkeklere oranla çok daha önemlidir. Mağazanın konumu kadar diş görüntüsü de tüketiciyi kendisine çekmelidir. İlk izlenim oluşturan diş görünüş, mağazanın imajı ve atmosferi ile ilgili tüketiciye bilgi vermektedir (Arslan, 2011: 64; Aydın, 2013: 194). Hedef kitleye uygun dizayn edilen dış görüntü, tüketiciyi içeriye davet etmeyi başarır (Kachaganova, 2008, 36; Aslan, 2016: 30). Bundan dolayı mağazanın dış görüntüsü ile iç dizaynının uyumlu olması önemlidir. Bu sebeple, mağaza içine giren tüketici herhangi bir sürprizle karşılaşmamalıdır. Bu bağlamda mağazanın dışı ile içinin uyumlu olması önemlidir (Arslan, 2011: 76). Mağazada kullanılan renklerden, 1şı̆̆a, rafların düzenine kadar birçok unsur mağaza atmosferini oluşturmada yardım etmektedir. Özellikle insan davranışına yön verdiği bilinen renkler (Madden, Hewett ve Roth, 2000: 92; Arslan, 2011: 81; Bellizzi ve Hite, 1992: 348) mağaza atmosferi ve istenilen imajı oluştururken önem arz etmektedir. Labrecque ve Milne (2012: 715)'nin çalışmasına göre, kişilerin demografik özelliklerinin renklere olan 
tutumlarında etkisi bulunmaktadır. Bu bağlamda markalarda mağazalarında kullanacakları renklerin seçimlerini yaparken hedef kitlelerini göz önünde bulundurmaktadırlar. Diğer bir deyişle, markalar hedef kitlelerinde oluşturmak istedikleri imaja ve atmosfere göre rengi seçmelidir (Okay, 2013: 120). Mağazada doğru rengin kullanılmasının yanı sıra o rengi iyi yansıtacak aydınlatmanın kullanılması da önemlidir. Çünkü ışığın doğru kullanılması, tüketicinin arzularını harekete geçirebilmektedir (Bayraktar, 2011: 28; Acar ve Sönmez, 2015: 287). Işık doğru kullanılmazsa mağazada sergilenen ürünün görüntüsünü de iyi bir şekilde yansitamaz (Tuğsal, 2014: 96). Sadece materyaller değil, insan unsurları da mağaza atmosferini etkilemektedir. Bu bağlamda, mağaza çalışanlarının görüntüleri ve davranışları da mağaza atmosferini etkilemektedir (Fettahlığlu, 2014). Mağaza çalışanlarının olumlu davranışları, tüketicilerin mağaza tercihinde ve satın alma davranışı göstermesinde önemli bir etkendir (Odabaşı ve Barış, 2006: 384).

Yukarıdaki bilgiler ışı̆̆ında mağaza atmosferini oluşturan birçok etken bulunduğu görülmektedir. Bu etkenler mağazanın imajına, hedef kitlesine, verilmek istenen mesaja, yaratılmak istenen atmosfere göre belirlenmelidir. Her unsur birbiriyle uyumlu olmalı ve markanın konumuna göre dizayn edilmelidir.

\section{Yöntem}

\section{Araştırmanın Amacı, Kısıtları, Türü ve Hipotezleri}

Günümüzde kozmetik pazarının dünyadaki büyüme hızı yılda \%5 civarındadır. Yaşlı nüfusun artması ve kozmetik tüketimine yönlenmeleri, erkeklerin giderek daha fazla kozmetik ürünleri tüketiyor olmaları pazarın büyüme sebeplerinden sadece bazılarıdır ('Kozmetik Tüketim...', 2002). Bu bağlamda araştırmanın temel amacı tüketicilerin kozmetik mağazalarının atmosferine verdikleri önem irdelenmiştir. Diğer bir deyişle araştırmada, tüketicilerin yaş, cinsiyet, medeni durum gibi demografik değişkenlikleri ile mağaza atmosferine verdikleri öneme yönelik puanları arasında fark olup olmadığının belirlenmesi amaçlanmıştır. Bu çalışma ana kütlenin özelliklerini ortaya koyma amacıyla çalışma tanımsal araştırma niteliğinde olup (Gegez, 2013: 30), bilgi ve verilerin daha kolay elde edilmesinden dolayı tesadüfi olmayan örnekleme çeşitlerinden biri olan kolayda örnekleme yöntemi (Kurtuluş, 2010: 63) tercih edilmiştir. Bu bağlamda, araştırmada 320 katılımcıya yüz yüze anket uygulanmıştır.

Aşağıda yer alan hipotezler Yüksekbilgili (2016)'nin, Mcdonnell (2007)'in, Arslan (2011)'in, Levy ve Weitz (2001)'in, Arslan (2016)'nın, Bellizzi ve Hite (1992) çalışmalarından yararlanılarak geliştirilmiştir.

Araştırmanın test etmeyi amaçladığı hipotezler şöyledir:

H1: Mağaza atmosferine verilen önem ile tüketicilerin cinsiyeti arasında fark vardır.

H2: Mağaza atmosferine verilen önem ile tüketicilerin yaşı arasında fark vardır. 
H3: Mağaza atmosferine verilen önem ile tüketicilerin eğitim durumu arasında fark vardir.

H4: Mağaza atmosferine verilen önem ile tüketicilerin medeni durumu arasında fark vardir.

H5: Mağaza atmosferine verilen önem ile tüketicilerin aktif iş hayatında yer alması arasinda fark vardir.

H6: Mağaza atmosferine verilen önem ile tüketicilerin gelir durumu arasında fark vardır.

\section{Ana Kütle, Örnek Kütlenin Seçimi ve Veri Toplama Yöntemi}

Araştırma, zaman ve mali kısıtlarından dolayı, farklı müşteri segmentlerine ulaşmak amacıyla Nişantaşı bölgesinde uygulanmıştır. Anket çalışmasında Nişantaşı bölgesi en fazla mağaza sayısına sahip cadde olmasından dolayı ('İstanbul Alışveriş...', 2017) seçilmiştir. Bu bağlamda araştırmanın ana kütlesini Nişantaşı bölgesinde bulunan tüketiciler oluşturmaktadır. Araştırmada, veri toplamak için bilgi ve verilerin en kolay toplanabildiği kolayda örnekleme yöntemi (Kurtuluş, 2010: 63) kullanılmıştır. Bu sebeple veri toplamak amacıyla Nişantaşı caddesinin çevresindeki kozmetik mağazalarında dolaşan tüketicilerle yüz yüze anket uygulaması yapılmıştır. Fakat araştırma sadece İstanbul ilinde bulunan Nişantaşı bölgesinde gerçekleştirildiği için sonuçlarının Türkiye’ye genellenmesi gibi bir durum söz konusu değildir. Pazarlama araştırmalarında 'problem çözümüne yönelik yapılan araştırmalar' da tipik örnek hacminin 300 ile 500 arasında olması gerekmektedir (Naresh ve Birks, 2000: 351). Bu sebeple araştırmada 320 kişilik bir örneklem miktarına ulaşılmak hedeflenmiştir.

\section{Anket Sorularının Hazırlanması, Test Edilmesi ve Araştırmada Kullanılan Ölçekler}

Veri toplama amacıyla araştırmada anket uygulanmıştır. Kullanılan anket formu iki bölümden oluşmaktadır. İlk bölümde katılımcıların demografik özelliklerini belirlemek amacıyla ilgili sorular sorulmaktadır. İkinci bölümde ise katılımcıların mağaza atmosferine verdikleri önemi ölçmeye yönelik Yüksekbilgili (2016)'nin 'hızlı moda tüketicilerinin mağaza atmosferine verdikleri önemin ölçülmesi için bir ölçek geliştirme çalışması: Avrasya mağaza atmosfer ölçeği' adlı çalışmasından faydalanılmıştır. Bu bağlamda, ölçekte yer alan her bir ifadenin ilgili kategorisi 5'li skala üzerinden değerlendirilmektedir.

\section{Araştırmada Mağaza Atmosferine Verilen Önem Ölçeğinin Güvenirlilik Analizi}

Araştırmada, "Mağaza Atmosferine Verilen Önem" ölçeğinin güvenirliğini hesaplama amacıyla iç tutarlılık katsayısı olan "Cronbach Alpha" hesaplanmıştır. Ölçeğin genel güvenirliği alpha=0.950 bulunmuştur. Bu bağlamda, ölçeğin güvenirliliğinin yüksek olduğu söylenebilir. Daha sonra ölçeğin yapı geçerliliğinin ortaya koyma amacıyla faktör analizi yöntemi uygulanmıştır. Yapılan Barlett testi sonucunda $(\mathrm{p}=0.000<0.05)$ faktör analizinealınan değişkenler arasında ilişkinin olduğu tespit edilmiştir. Yapılan test sonucunda $(\mathrm{KMO}=0.920>0,60)$ örnek büyüklüğünün faktör analizi uygulanması için yeterli olduğu tespit edilmiştir. KMO değerleri, örneklem hacminin ve elde edilen verilerin çalışma için iyi 
derecede uygun olduğu (0.915), Bartlett's küresellik testi anlamlılık düzeyinin ise $(p<.001)$ normal dağıldığı görülmektedir. Faktör analizi sonucunda değişkenler toplam açıklanan varyansı \%65.197 olan 6 faktör altında toplanmıştır. Güvenirliğine ilişkin bulunan alpha ve açıklanan varyans değerine göre "Mağaza Atmosferine Verilen Önem" ölçeğinin geçerli ve güvenilirbir araçolduğu anlaşılmıştır. Diğer bir deyişle çalışmada, güvenirliğine ilişkin elde edilen değerlere göre "Tüketicilerin Mağaza Atmosferine Verdikleri Önem” ölçeğinin geçerli ve güvenilir olduğu anlaşılmıştır.

Cronbach's Alpha Katsayısının değerlendirilmesinde kullanılan değerlendirme kriteri (Özdamar, 2004);

$$
\begin{aligned}
& 0,00 \leq \alpha<0,40 \text { ise ölçek güvenilir değildir. } \\
& 0,40 \leq \alpha<0,60 \text { ise ölçek düşük güvenilirliktedir. } \\
& 0,60 \leq \alpha<0,80 \text { ise ölçek oldukça güvenilirdir. } \\
& 0,80 \leq \alpha<1,00 \text { ise ölçek yüksek derecede güvenilir bir ölçektir. }
\end{aligned}
$$

Araştırmada elde edilen bulgular Statistical Package for Social Sciences for Windows 22.0 programı kullanılarak analiz edilmiştir. Verileri değerlendirilirken sayı, yüzde, ortalama, standart sapma gibi tanımlayıcı istatistiksel metotları kullanılmıştır. Niceliksel verilerin karşılaştırılmasında iki grup arasındaki farkı t-testi, ikiden fazlagrupdurumunda parametrelerin gruplararasıkarşılaştırmalarında Tekyönlü (One way) Anova testi yapılmıştır. Bu bağlamda, elde edilen bulgular \%95 güven aralığında \%5 anlamlılık düzeyinde değerlendirilmiştir.

\section{Bulgular}

Bu bölümde, araştırma probleminin çözümü için, araştırmaya katılan İstanbul'daki, Nişantaşı bölgesinde bulunan kozmetik mağazaların bulunduğu caddelerde dolaşan tüketicilerden toplanan verilerin analizi sonucunda elde edilen bulgular yer almaktadır.

Tablo 1: Katılımciların Demografik Verileri

\begin{tabular}{cccc}
\hline Tablolar & Gruplar & Frekans (n) & Yüzde (\%) \\
\hline Cinsiyet Grubu & Kadın & 120 & 37,5 \\
& Erkek & 200 & 62,5 \\
& $15-20$ & 35 & 10,9 \\
& $21-26$ & 232 & 72,5 \\
\multirow{3}{*}{ Yaş Grubu } & $27-32$ & 35 & 10,9 \\
& $33-38$ & 14 & 4,4 \\
& $39-45$ & 1 & 0,3 \\
& 46 ve üstü & 3 & 0,9 \\
Eğitim Durumu & İlköğretim & 6 & 0,6 \\
& Lise & 12 & 1,9 \\
& Ön Lisans & 250 & 3,8 \\
& Lisans & 50 & 78,1 \\
& Lisans üstü & &
\end{tabular}




\begin{tabular}{|c|c|c|c|}
\hline \multirow[t]{2}{*}{ Medeni Durum } & Evli & 21 & 6,6 \\
\hline & Bekâr & 299 & 93,4 \\
\hline \multirow[t]{4}{*}{ Çalışma Durumu } & Evet & 124 & 38,8 \\
\hline & Hayır & 194 & 60,6 \\
\hline & 1000 TL ve altı & 149 & 46,6 \\
\hline & 1000- 2999 TL & 117 & 36,6 \\
\hline \multirow[t]{2}{*}{ Gelir Durumu } & 3000- $4.999 \mathrm{TL}$ & 29 & 9,1 \\
\hline & 5000 TL ve üzeri & 25 & 7,8 \\
\hline \multicolumn{2}{|c|}{ TOPLAM } & 320 & 100 \\
\hline
\end{tabular}

Yukarıdaki tabloda da görüldüğü gibi araştırmaya katılanların 200'ü $(\% 62,5)$ erkek, 120'si $(\% 37,5)$ kadındır. Ayrıca katılımcıların yaş değişkenliği incelendiğinde; katılanların 35'i (\%10,9) 15-20, 232'si (\%72,5) 21-26, 35'i (\%10,9) 27-32, 14'ü (\%4,4) 33-38, 1'i (\%0,3), 39-45, 3'ü $(\% 0,9) 46$ ve üstü olarak dağılmaktadır. Diğer bir deyişle katılımcıların çoğunluğunu 2126 yaş arasındaki gençler oluşturmaktadır. Katılımcıların eğitim durumu değişkenine göre 2'si $(\% 0,6)$, ilköğretim, 6's1 (\%1,9) lise, 12'si (\%3,8) ön lisans, 250'si (\%78,1) lisans, 50'si $(\% 15,6)$ lisansüstü olarak dağılmaktadır. Ankete katılanların medeni durumu değişkenine göre 21'i $(\% 6,6)$ evli, 299'u $(\% 93,4)$ bekâr olarak dağılmaktadır. Bu bağlamda katılımcıların çoğunun bekâr olduğu söylenebilir. Katılımcıların çalışma durumu değişkenine göre durumları ise, 124'ü $(\% 38,8)$ çalışıyor, 194'ü $(\% 60,6)$ çalışmıyor olarak dağılmaktadır. Bu bağlamda katılımcıların çoğunun gelir durumlarının olduğu görülmektedir. Ankete katılanların gelir durumu değişkenine göre 149'u (\% 46,6) 1000 TL'denaz, 117'si (\%36,6) 1000-2999 TL, 29'u (\%9,1) 3000 - 4.999 TL, 25'i (\% 7,8) 5000 TL ve üzeri kazanıyor olarak dağılmaktadır. Elde edilen veriler ışığında katılımcıların maddi durumlarının çok yüksek olmadığı söylenebilir.

\section{Mă̆aza Atmosferine Verilen Önem Boyutunda Dă̆ılım}

Araştırmaya katılan katılımcıların "Mağaza Atmosferine Verilen Önemin” ölçüldüğü anket sorularına verilen cevaplar incelendiğinde;

"7- Benim için kozmetik mağazasının ismi önemlidir." ifadesine İstanbul'da yaşayan katılımciların, \%17,2'si (n=55) kesinlikle katılmiyorum, \%16,3'ü (n=52) katılmıyorum, \%23,8'i $(n=76)$ ne katıliyorum ne katılmiyorum, \%26,9'u $(n=86)$ katılıyorum, \%15,9'u $(n=51)$ kesinlikle katılıyorum yanıtını vermiştir.

"8- Benim için kozmetik mağazasının çalışanlarının davranışları önemlidir." ifadesine İstanbul'da yaşayan katılımcıların, \%5,3'ü $(n=17)$ kesinlikle katılmıyorum, \%9,4'ü $(n=30)$ katılmıyorum, \%10,3'ü (n=33) ne katılıyorum ne katılmıorum, \%39,1'i (n=125) katılıyorum, $\% 35,9^{\prime} \mathrm{u}(\mathrm{n}=115)$ kesinlikle katılıyorum yanıtını vermiştir.

"9- Benim için kozmetik mağazasında koridorların dağılımı önemlidir." ifadesine katılımcıların, \%10,0'u (n=32) kesinlikle katılmıyorum, \%9,4'ü (n=30) katılmıyorum, \%28,8'i $(\mathrm{n}=92)$ ne katılıyorum ne katılmıyorum, \%31,6's1 (n=101) katılıyorum, \%20,3’ü (n=65) kesinlikle katılıyorum yanıtınıvermiştir.

"10- Benim için kozmetik mağazasında ürünlerin fiyat etiketleri önemlidir." ifadesine katılımciların, \%5,9'u (n=19) kesinlikle katılmıyorum, \%8,8'i (n=28) katılmıyorum, \%10,6's1 
(n=34) ne kat1liyorum ne katılmıyorum, \%32,8' i (n=105) katıliyorum, \%41,9'u (n=134) kesinlikle katılıyorum yanıtını vermiştir.

"11- Benim için kozmetik mağazasının tasarımında kullanılan yer döşemeleri ve zemini

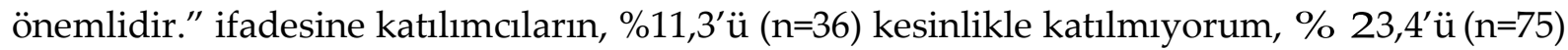
katılmıyorum, \% 35,9'u(n=115) ne katıliyorum ne katılmıyorum, \%20,3' $\ddot{\mathrm{u}}(\mathrm{n}=65)$ katıliyorum, \% 9,1'i (n=29) kesinliklekatılıyorum yanıtını vermiştir.

"12- Benim için kozmetik mağazasında çalışanların bilgi düzeyi önemlidir." ifadesine katılımcıların, \%4,4'ü ( $\mathrm{n}=14)$ kesinlikle katılmıyorum, \%8,4'ü ( $\mathrm{n}=27)$ katılmıyorum, \%13,8'i $(\mathrm{n}=44)$ ne katıliyorum ne katılmiyorum, \%39,7'si ( $\mathrm{n}=127)$ katıllyorum, \%33,8' $\mathrm{i}$ ( $\mathrm{n}=108)$ kesinlikle katılıyorum yanıtını vermiştir. İstanbul'daki katılımcıların çoğunluğu mağaza çalışanlarının bilgi düzeylerine önem verdikleri söylenebilir.

"13- Benim için kozmetik mağazasının mağaza çevresi önemlidir." ifadesine katılımcıların, \%9,1'i (n=29) kesinlikle katılmiyorum, \%16,9'u ( $n=54)$ katılmiyorum, \%35,6's1 (n=114) ne katılıyorum ne katılmıyorum, \%29,7'si (n=95) katılıyorum, \%8,8'i (n=28) kesinlikle katılıyorum yanıtını vermiştir. Katılımcıların çoğunluğunun mağazanın çevresine önem verdikleri görülmektedir.

"14- Benim için kozmetik mağazasının ışıklandırması önemlidir." ifadesine katılımcıların, \%5,0'1 (n=16) kesinlikle katılmiyorum, \%12,2'si (n=39) katılmiyorum, \%23,1'i ( $n=74)$ ne katıliyorum ne katılmiyorum, \%43,4'ü (n=139) katıliyorum, \%16,3'ü $(n=52)$ kesinlikle katılıyorum yanıtını vermiştir.

"15- Benim için kozmetik mağazasında duvar dekorasyonu önemlidir." ifadesine katılımciların, \%7,8'i (n=25) kesinlikle katılmıyorum, \%13,8'i (n=44) katılmıorum, \%40,3'ü $(\mathrm{n}=129)$ ne katılıyorum ne katılmiyorum, \%30,6'si $(\mathrm{n}=98)$ katılıyorum, \%7,5'i (n=24) kesinlikle katılıyorum yanıtı vermiştir.

"16- Benim için kozmetik mağazasında çalışanların giyimi önemlidir." ifadesine katılımcıların, \%5,6'si (n=18) kesinlikle katılmiyorum, \%12,2'si ( $n=39$ ) katılmiyorum, \%29,7'si ( $n=95)$ ne katılıyorum ne katılmıyorum, \%35,3'ü (n=113) katıliyorum, \%17,2'si $(n=55)$ kesinlikle katılıyorum yanıtını vermiştir.

"17- Benim için kozmetik mağazasının vitrini önemlidir." ifadesine katılımcıların, \%7,2'si $(\mathrm{n}=23)$ kesinliklekatılmiyorum, \%10,9'u ( $\mathrm{n}=35)$ katılmiyorum, \%23,8' $\mathrm{i}(\mathrm{n}=76)$ ne kat1lyorum ne katılmiyorum, \%40,9'u ( $n=131)$ katıliyorum, \%17,2'si $(n=55)$ kesinlikle katılıyorum yanitını vermiştir.

"18- Benim için kozmetik mağazasının temizliği önemlidir." ifadesine katılımcıların, \%8,1'i $(\mathrm{n}=26)$ kesinlikle katılmiyorum,\%4,7'si ( $\mathrm{n}=15)$ katılmıyorum, \%4,4'i ( $=14)$ ne katılıyorum ne katılmıyorum, \%30,3'ü (n=97) katıllyorum, \%52,5'i $(n=168)$ kesinlikle katılıyorum yanıtını vermiştir.

"19- Benim için kozmetik mağazasında boşlukların dağılımı önemlidir." ifadesine katılımcların, \%7,8'i (n=25) kesinlikle katılmıyorum, \%7,2'si (n=23) katılmıyorum, \% 35,3'ü $(n=113)$ ne katıliyorum ne katılmiyorum, \%33,4'ü ( $n=107)$ katıliyorum, \%16,3'ü (n=52) kesinlikle katılıyorum yanıtını vermiştir.

“20- Benim için kozmetik mağazasında ses düzeyi önemlidir." ifadesine İstanbul' da yaşayan katılımciların, \%5,3'i (n=17) kesinlikle katılmıorum, \%12,8'i (n=41) katılmıyorum, \% 26,6's1 
( $\mathrm{n}=85)$ ne katıliyorum ne katılmiyorum, \% 35,6's1 (n=114) katıliyorum, \% 19,7'si (n=63) kesinlikle katılıyorum yanıtını vermiştir.

"21- Benim için kozmetik mağazasının tabelası önemlidir." ifadesine İstanbul'da yaşayan katılımcıların, \%8,4'ü (n=27) kesinlikle katılmıyorum, \%16,9'u (n=54) katılmıyorum, \%35,3'ü $(\mathrm{n}=113)$ ne katıliyorum ne katılmiyorum, \%23,8'i $(\mathrm{n}=76)$ katıliyorum, \%15,6's1 (n=50) kesinlikle katılıyorum yanıtını vermiştir.

"22- Benim için kozmetik mağazasının bulunduğu binanın boyutu önemlidir." ifadesine İstanbul'dayaşayankatılımcıların, \%18,1'i (n=58) kesinlikle katılmıyorum, \%21,9'u (n=70) katılmiyorum, \%40,9'u (n=131) ne katıliyorum ne katılmiyorum, \%12,2'si (n=39) katıliyorum, $\%$ 6,9'u (n=22) kesinliklekatılıyorum yanıtını vermiştir.

“23- Benim için kozmetik mağazasının girişi önemlidir." ifadesine katılımcıların, \%7,8'i (n=25) kesinlikle katılmiyorum, \%11,9'u (n=38) katılmiyorum, \%35,6's1 ( $\mathrm{n}=114)$ ne katıliyorum ne katılmiyorum, \%37,5'i (n=120) katıliyorum, \%7,2'si (n=23) kesinlikle katıliyorum yanitını vermiştir.

"24- Benim için kozmetik mağazasında ölü alanların olmaması önemlidir." ifadesine İstanbul'da yaşayan katılımcıların, \%6,6's1 (n=21) kesinlikle katılmıorum, \%12,8'i (n=41) katılmıyorum, \%43,1'i (n=138) ne katılıyorum ne katılmıyorum, \%29,4'ü ( $n=94)$ katılıyorum, \%8,1'i (n=26) kesinlikle katılıyorum yanıtını vermiştir.

“25- Benim için kozmetik mağazasında çalan müzikler önemlidir." ifadesine katılımcıların, $\% 10,0$ 'u (n=32) kesinlikle katılmiyorum, \%12,2'si ( $n=39)$ katılmiyorum, \%27,8'i ( $=89$ ) ne katıliyorum ne katılmiyorum, \%33,4'ü $(n=107)$ katılıyorum, \%16,6's1 $(n=53)$ kesinlikle katılıyorum yanıtını vermiştir.

"26- Benim için kozmetik mağazasında çalışanların yaklaşımları önemlidir.” ifadesine katılımcıların, \% 3,4'ü (n=11) kesinlikle katılmiyorum, \%9,4'ü (n=30) katılmıyorum, \%5,9’u $(\mathrm{n}=19)$ ne katılıyorum ne katılmıyorum, \%41,3'ü (n=132) katılıyorum, \%40,0'1 (n=128) kesinlikle katılıyorum yanıtını vermiştir.

"27- Benim için kozmetik mağazasının bulunduğu binanın mimarisi önemlidir." ifadesine İstanbul'da yaşayan katılımcıların, \%13,4' $\ddot{u}(\mathrm{n}=43)$ kesinlikle katılmıyorum, \%19,4' $\ddot{u} \quad(n=62)$ katılmiyorum, \%45,6'si (n=146) ne katılıyorum ne katılmıyorum, \%14,7'si ( $\mathrm{n}=47)$ katıliyorum, $\% 6,9^{\prime} \mathrm{u}(\mathrm{n}=22)$ kesinlikle katılıyorum yanıtını vermiştir.

"28- Benim için kozmetik mağazasında çalışanların temizliği ve kişisel bakımı önemlidir." ifadesine İstanbul'da yaşayan katılımcıların, \%7,8'i (n=25) kesinlikle katılmıyorum, \%3,8'i $(\mathrm{n}=12)$ katılmiyorum, \%10,9'u $(\mathrm{n}=35)$ ne katıliyorum ne katılmiyorum, \%34,1'i ( $\mathrm{n}=109)$ katılıyorum, \%43,4'ü $(\mathrm{n}=13)$ kesinlikle katılıyorum yanıtını vermiştir.

“29- Benim için kozmetik mağazasının kullanılan kartlar (dön kart, ürün tanıtım kartları, kampanya kartları, indirim kartları, ölçü kartları, bilgilendirme kartları gibi...) önemlidir." ifadesine katılımcıların, \% 4,7'si (n=15) kesinlikle katılmıyorum, \%11,3' ̈̈ (n=36) katılmıyorum, \%25,0'i (n=80) ne katıliyorum ne katılmiyorum, \%30,3'ü (n=97) katıllyorum, \%28,8'i (n=92) kesinlikle katılıyorum yanıtını vermiştir.

“30- Benim için kozmetik mağazasının, mağaza boyutu önemlidir." ifadesine İstanbul'da yaşayan katılımcıların, \%8,8'i (n=28) kesinlikle katılmıyorum, \%12,5'i (n=40) katılmıyorum, 
\%44,7'si (n=143) ne katıliyorum ne katılmiyorum, \%25,0'i (n=80) katılıyorum, \%9,1'i (n=29) kesinlikle katılıyorum yanıtını vermiştir.

“31- Benim için kozmetik mağazasının tasarımında kullanılan renkler önemlidir.” ifadesine İstanbul'da yaşayan katılımcıların, \%4,4'ü (n=14) kesinlikle katılmıyorum, \%11,3'ü (n=36) katılmıyorum, \%36,9'u (n=118) ne katıliyorum ne katılmıyorum, \%36,6's1 (n=117) katıliyorum, $\% 10,9^{\prime} \mathrm{u}(\mathrm{n}=35)$ kesinlikle katılıyorum yanıtını vermiştir.

"32- Benim için kozmetik mağazasında kullanılan işaretler (yönlendirme işaretleri) önemlidir." ifadesine katılımcıların, \% 5,9'u (n=19) kesinlikle katılmıyorum, \%10,9'u (n=35) katılmiyorum, \%22,2'si (n=71) ne katıliyorum ne katılmiyorum, \%40,9'u (n=131) katıliyorum, $\% 20,0$ 'si (n=64) kesinlikle katılıyorum yanıtını vermiştir.

"33- Benim için kozmetik mağazasında bulunan ekipmanlar (aynalar, ürün taşıma çantaları, hediye paketi, poşetler gibi...) önemlidir." ifadesine İstanbul'da yaşayan katılımcıların, \%6,6'si $(\mathrm{n}=21)$ kesinlikle katılmiyorum, \%7,8'si ( $\mathrm{n}=25)$ katılmiyorum, \%19,7'si ( $\mathrm{n}=63)$ ne katıliyorum ne katılmıyorum, \%43,4'ü (n=139) katılıyorum, \%22,5'i (n=72) kesinlikle katılıyorum yanıtını vermiştir.

“34- Benim için kozmetik mağazasının bulunduğu yerde park olanağı olması önemlidir." ifadesine İstanbul'da yaşayan katılımcıların, \%11,6's1 (n=37) kesinlikle katılmıyorum. \%19,1'i $(\mathrm{n}=61)$ katılmiyorum, \%42,2'si $(\mathrm{n}=135)$ ne katıliyorum ne katılmiyorum, \%14,1'i ( $\mathrm{n}=45)$ katılıyorum, \%13,1'i(n=42) kesinlikle katılıyorum yanıtını vermiştir.

“35- Benim için kozmetik mağazasında mağaza trafiği ve trafik akışı önemlidir.” ifadesine İstanbul'da yaşayan katılımcıların, \%8,8'i ( $n=28)$ kesinlikle katılmıyorum, \%12,5'i (n=40) katılmıyorum, \%27,2'si (n=87) ne katılıyorum ne katılmıyorum, \%34,7'si (n=111) katıliyorum, $\% 16,9^{\prime} \mathrm{u}(\mathrm{n}=54)$ kesinlikle katılıyorum yanıtını vermiştir.

“36- Benim için kozmetik mağazasının kokusu önemlidir." ifadesine İstanbul'da yaşayan katılımciların, \%5,0'i (n=16) kesinlikle katılmiyorum, \%4,7'si (n=15) katılmıyorum, \%13,8'i $(\mathrm{n}=44)$ ne katıliyorum ne katılmiyorum, \%41,6'si $(\mathrm{n}=133)$ katıliyorum, \%35,0'i $(\mathrm{n}=112)$ kesinlikle katılıyorum yanıtını vermiştir.

“37- Benim için kozmetik mağazasının ürünlerin gruplandırılma şekli önemlidir.” ifadesine İstanbul'da yaşayan katılımcların, \%5,9'u (n=19) kesinlikle katılmıyorum, \%8,1'i (n=26) katılmiyorum, \%15,6's1 (n=50) ne katıliyorum ne katılmiyorum, \%36,9'u (n=118) katıliyorum, \%33,4'ü (n=107) kesinlikle katılıyorum yanıtını vermiştir.

"38- Benim için kozmetik mağazasının sıcaklığı önemlidir." ifadesine İstanbul'da yaşayan katılımciların, \%6,9'u (n=22) kesinlikle katılmiyorum, \%6,6'sı (n=21) katılmiyorum, \%25,3'ü $(\mathrm{n}=81)$ ne katılıyorum ne katılmıyorum, \%43,4'ü ( $\mathrm{n}=139)$ katılıyorum, \%17,8'i $(\mathrm{n}=57)$ kesinlikle katılıyorum yanıtını vermiştir.

“39- Benim için kozmetik mağazasında ürünlerin kullanım kılavuzları önemlidir." ifadesine İstanbul'da yaşayan katılımcıların, \%2,2'si (n=7) kesinlikle katılmıyorum, \%11,9'u (n=38) katılmıyorum, \%21,9'u (n=70) ne katıliyorum ne katılmiyorum, \%39,4'ü (n=126) katıliyorum, $\% 24,7$ 'si (n=79) kesinlikle katılıyorum yanıtını vermiştir.

"40- Benim için kozmetik mağazasında bekleme alanı (oturma imkânları, çocuk alanları gibi...) önemlidir." ifadesine İstanbul'da yaşayan katılımcıların, \%6,6'sı (n=21) kesinlikle 
katılmiyorum, \%12,2'si (n=39) katılmiyorum, \%30,0'u (n=96) ne katıliyorum ne katılmiyorum, \%25,3'ü (n=81) katılıyorum, \%25,9'u (n=83) kesinlikle katılıyorum yanıtını vermiştir.

“41- Benim için kozmetik mağazasının ürünlerinin deneme alanlarının yerleşimi önemlidir.” ifadesine katılımciların, \% 4,7'si (n=15) kesinlikle katılmıyorum, \%7,8'i ( $\mathrm{n}=25)$ katılmıorum, \%22,5'i (n=72) ne katıliyorum ne katılmiyorum, \%34,7'si (n=111) katıliyorum, \%30,3'ü (n=97) kesinlikle katılıyorum yanıtını vermiştir.

\section{Ölçeklere Ait Ortalama ve Standart Sapma Değerleri}

Tablo 2. Mağaza Atmosferine Verilen Önem Düzeyleri

\begin{tabular}{llllll}
\hline \multirow{3}{*}{ Mağaza Atmosferine Verilen Önem } & N & Ort & Ss & Min. & Max. \\
& 320 & 3,482 & 1,111 & 1,000 & 5,000 \\
\hline
\end{tabular}

Ankete katılanların mağaza atmosferine verilen önem düzeyi ortalaması görülmektedir.

Mağaza Atmosferine Verilen Önem ile Demografik Özellikler Arasındaki Fark

Tablo 3. Katılımcıların Mağaza Atmosferine Verdikleri Önem ile Cinsiyetleri

Arasındaki Fark

\begin{tabular}{|c|c|c|c|c|c|c|c|c|}
\hline \multicolumn{3}{|c|}{ Kadın } & \multicolumn{6}{|c|}{ Erkek } \\
\hline Adet & Ort. & $\begin{array}{l}\text { Std. } \\
\text { Sapma }\end{array}$ & Adet & Ort. & $\begin{array}{l}\text { Std. } \\
\text { Sapma }\end{array}$ & $\begin{array}{l}\mathrm{t} \text { testi } \\
\text { sonucu }\end{array}$ & $\begin{array}{l}\text { Kisit } \\
\text { (df) }\end{array}$ & Olasılık \\
\hline 120 & 3,6176 & ,59862 & 200 & 3,4612 & ,70972 & $-2,804$ & 318 & ,005 \\
\hline
\end{tabular}

Katılımcıların mağaza atmosferine verdikleri önem puanıortalamalarının cinsiyetdurum değişkenine göreanlamlıbirfarklılıkgösterip göstermediğini belirlemek amacıyla yapılan t-testi sonucunda grup ortalamaları arasındaki fark istatistiksel açıdan anlamlı bulunmuştur. $\mathrm{Bu}$ sebeple tüketicilerin cinsiyet durumları ile mağaza atmosferine verdikleri önem puanları arasında fark vardır ve Hipotez:1 kabul edilmiştir. Araştırmaya katılan kadın katılımcıların mağaza atmosferine verdikleri önem puanı $(x=3,617)$, araştırmayakatılan erkek katılımcıların mağaza atmosferine verdikleri önem puanından $(\mathrm{x}=3,461)$ yüksek bulunmuştur. 
Tablo 4. Katılımcıların Mağaza Atmosferine Verdikleri Öneme ile Yaşları Arasındaki Farkı

\begin{tabular}{lccccc}
\hline & Adet & Ortalama & Standart Sapma & $\mathbf{F}$ & $\mathbf{p}$ \\
\hline 15-20 yaş & 35 & 3,3502 &, 71989 & 2,646 &, 023 \\
$21-26$ yaş & 232 & 3,4531 &, 70594 & & \\
$27-32$ yaş & 35 & 3,7918 &, 34044 & & \\
33-38 yaş & 14 & 3,5571 &, 42949 & & \\
39-45 yaş & 1 & 4,4286 &. & & \\
46 ve üzeri yaş & 3 & 2,9714 &, 84177 & & \\
Toplam & 320 & 3,4820 &, 67748 & & \\
\hline
\end{tabular}

Araştırmaya katılan katılımcıların mağaza atmosferine verdikleri önem puanı ortalamalarının yaş grubu değişkenine göre anlamlı bir farklılık gösterip göstermediğini belirlemek amacıyla tek yönlü varyans analizi (Anova) sonucunda grup ortalamaları arasındaki fark istatistiksel açıdan anlamlı bulunmuştur. Tüketicilerin yaşları ile mağaza atmosferine verdikleri önem puanlarıarasında fark bulunduğu için araştırmanın Hipotez 2'si kabul edilmiştir. Yaş grubu 27-32 yaş olan katılımcıların mağaza atmosferine verdikleri önem puanı $(3,791 \pm 0,340)$, yaş grubu 46 ve üzeri olan katılımcıların puanından $(2,971 \pm 0,841)$

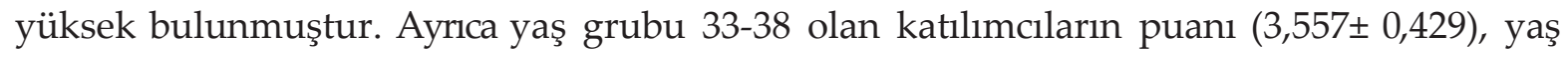
grubu 15-20 yaş olan katılımcıların mağaza atmosferine verdikleri önem puanından $(3,350 \pm$ 0, ,719) yüksek bulunmuştur.

Tablo 5. Katılımcların Mağaza Atmosferine Verdikleri Öneme ile Eğitim Durumları Arasindaki Fark

\begin{tabular}{lccccc}
\hline & Adet & Ortalama & Standart Sapma & F & p \\
\hline İlköğretim & 2 & 3,4571 &, 04041 & 2,428 &, 048 \\
Lise & 6 & 3,2095 & 1,02119 & & \\
Ön Lisans & 12 & 3,6952 &, 94387 & & \\
Lisans & 250 & 3,4315 &, 68762 & & \\
Lisansüstü & 50 & 3,7166 &, 43533 & & \\
Toplam & 320 & 3,4820 &, 67748 & & \\
\hline
\end{tabular}

Ankete katılan katılımcıların mağaza atmosferine verdikleri önem puanı ortalamalarının eğitim durumu değişkenine göre anlamlı bir farklılık gösterip göstermediğini belirlemek amacıyla yapılan tek yönlü varyans analizi (Anova) sonucunda grup ortalamaları arasında istatistiksel açıdan anlamlı bir fark bulunmuştur. Bu sebeple çalışmanın Hipotez:3'ü kabul edilmiştir. Eğitim durumu lisansüstü olan katılımcıların mağaza atmosferine verdikleri önem puanı $(3,716 \pm 0,435)$, eğitim durumu lise olan katılımcıların puanından $(3,209 \pm 1,021)$ yüksek bulunmuştur. Katılımcılardan eğitim durumu ön lisans olanların mağaza atmosferine verdikleri önem puanı $(3,695 \pm 0,943)$, lise olan katılımcıların puanından $(3,209 \pm$ 1,021) yüksek bulunmuştur. 
Tablo 6. Katılımcıların Mağaza Atmosferine Verildikleri Önem ile Medeni Durumları Arasındaki Fark

\begin{tabular}{|c|c|c|c|c|c|c|c|c|}
\hline \multicolumn{3}{|c|}{ Evli } & \multicolumn{6}{|c|}{ Bekâr } \\
\hline Adet & Ortalama & $\begin{array}{c}\text { Std. } \\
\text { Sapma }\end{array}$ & Adet & Ortalama & $\begin{array}{c}\text { Std. } \\
\text { Sapma }\end{array}$ & $\begin{array}{l}\mathrm{t} \text { testi } \\
\text { sonucu }\end{array}$ & Kisit (df) & Olasılık \\
\hline 21 & 3,5197 & 48928 & 299 & 3,4793 & 68931, & ,264 & 318 & 792 \\
\hline
\end{tabular}

Katılımcıların mağaza atmosferine verdikleri öneme yönelik puan ortalamalarının medeni durum değişkenine göre anlamlı bir farklılık gösterip göstermediğini belirlemek amacıyla yapılan t-testi sonucunda grup ortalamaları arasındaki fark istatistiksel açıdan anlamlı bulunmamıştır. Bu sebeple tüketicilerin medeni durumları ile mağaza atmosferine verdikleri önem puanları arasında fark yoktur. Bu bağlamda Hipotez 4 reddedilmiştir. Araştırmaya katılan evli katılımcıların mağaza atmosferine verdikleri önem puanı $(x=3,519)$, araştırmaya katılan bekâr katılımcıların mağaza atmosferine verdikleri önem puanından $(x=3,479)$ yüksek bulunmuştur.

Tablo 7. Katılımcıların Mağaza Atmosferine Verildikleri Önem ile Çalışma Durumları Arasindaki Fark

\begin{tabular}{lllllllll}
\hline Aktif & \multicolumn{9}{c}{ Aktif Değil } \\
\hline Adet & Ortalama & $\begin{array}{l}\text { Std. } \\
\text { Sapma }\end{array}$ & Adet & Ortalama & $\begin{array}{l}\text { Std. } \\
\text { Sapma }\end{array}$ & \multicolumn{1}{c}{ sonucu } \\
124 & 3,5737 &, 65043 & 194 & 3,4218 &, 69262 & 1,981 & 274,134 &, 049 \\
\hline
\end{tabular}

Katılımcıların mağaza atmosferine verdikleri öneme yönelik tutum puanıortalamalarının çalışma durum değişkenine göre anlamlı bir farklılık gösterip göstermediğini belirlemek amacıyla yapılan t-testi sonucunda grup ortalamaları arasındaki fark istatistiksel açıdan anlamlıbulunmuştur. Bu sebeple tüketicilerin aktif iş yaşamında bulunma durumları ile mağaza atmosferine verdikleri önem puanı arasında fark vardır. Bu bağlamda Hipotez: 5 kabul edilmiştir. Araştırmayakatılan aktif iş yaşamında bulunan katılımcılar ile mağaza atmosferine verdikleri önem puanı $(x=3,573)$, araştırmaya katılan aktif iş yaşamında bulunmayan katılımcıların mağaza atmosferine verdikleri önem puanından $(x=3,421)$ yüksek bulunmuştur.

Tablo 8. Katılımcıların Mağaza Atmosferine Verildikleri Önem İle Gelir Durumları Arasındaki Fark

\begin{tabular}{lccccc}
\hline & Adet & Ortalama & Standart Sapma & F & p \\
\hline 1.000 TL'den az & 149 & 3,4978 &, 69528 & 2,972 &, 032 \\
1.000-2.999 TL & 117 & 3,3673 &, 70809 & & \\
3.000-4.999TL & 29 & 3,7399 &, 52663 & &
\end{tabular}




\begin{tabular}{lccc}
$\begin{array}{l}5.000 \\
\text { üzeri }\end{array}$ & 25 & 3,6251 &, 45291 \\
Toplam & 320 & 3,4820 &, 67748 \\
\hline
\end{tabular}

Ankete katılan katılımcıların mağaza atmosferine verdikleri öneme yönelik puanı ortalamalarının gelir durumu değişkenine göre anlamlı bir farklılık gösterip göstermediğini belirlemek amacıyla yapılan tek yönlü varyans analizi (Anova) sonucunda grup ortalamaları arasındaki fark istatistiksel açıdan anlamlı bulunmuştur. Katılımcıların gelir durumu ile mağaza atmosferine verdikleri öneme yönelik puanları arasında anlamlı bir fark vardır. Bu bağlamda Hipotez 6 kabul edilmiştir. Gelir durumu3.000-4.999TL olankatılımclarınmağaza atmosferine verdikleri öneme yönelik puanı $(3,739 \pm 0,526)$, gelir durumu 1.000-2.999 TL olan katılımcların puanından $(3,367 \pm 0,708)$ yüksek bulunmuştur.

\section{Tartışma, Sonuç ve Öneriler}

Yapılan araştırmalara göre tüketicilerin çoğunluğu alışveriş kararını satın alma noktalarında gerçekleştirmektedir. Bu bağlamda markalar, tüketiciyi etkilemek ve satın alma kararını gerçekleştirmelerini sağlamak için satın alma noktası iletişimi çalışmaları yapmaktadır. Bu sebeple markalar, koku, müzik, tat, fiyatlandırma etiketi gibi unsurları kullanarak tüketiciyi etkilemekte ve satın alma noktası iletişimini sağlamaktadır. Satın alma noktası iletişiminin bir parçası olan koku, müzik, raf, ambalaj gibi unsurlar ile tüketici etkilendirilip bilgilendirilmektedir. Özellikle satın alma niyeti olmayan tüketiciler bu unsurlardan etkilenebilmekte ve satın alma kararı verebilmektedirler. Bu bağlamda, mağaza atmosferi satın alma noktası iletişimin önemli bir ayağıdır. Diğer bir deyişle, koku, müzik, aydınlatma, çalışanların veya müşterilerin görünüşleri, kullanılan renkler gibi unsurlar mağaza atmosferini oluşturmaktadır. Bu bağlamda, tüketicinin zihninde istedikleri imajı yaratmak, sürdürmek, müşterilerinin dikkatini çekmek ve rakiplerden ayrışmayı sağlamak için mağaza atmosferi markalar tarafindan sıklıkla kullanılmaktadır.

Çalışmada, katılımcıların mağaza atmosferine verilen önem puanı ortalamalarının cinsiyet durum değişkenine göre anlamlı bir farklılığın olup olmadığını belirlemek amacıyla t-testi yapılmıştır. Bu testin sonucunda grup ortalamaları arasındaki fark istatistiksel açıdan anlamlı bulunmuştur. Diğer bir değişle, tüketicilerin cinsiyet durumları ile mağaza atmosferine verdikleri önem puanları arasında fark vardır. Kadın katılımcıların mağaza atmosferine verdikleri önem puanı, araştırmaya katılan erkek katılımcıların puanından yüksek bulunmuştur. Bu sebeple, Hipotez:1 kabul edilmiştir. Tüketicinin demografik özelliklerinden biri olan yaş grubu değişkenine göre ise anlamlı bir farklılık olup olmadığını belirlemek amaciyla yapılan tek yönlü varyans analizi (Anova) sonucunda ise grup ortalamaları arasındaki fark istatistiksel açıdan anlamlı bulunmuştur. Yaş grubu 27-32 yaş olan katılımcıların mağaza atmosferine verdikleri önem puanı, yaş grubu 46 ve üzeri olan katılımcıların puanından yüksek bulunmuştur. Ayrıca yaş grubu 27-32 yaş olan katılımcıların puanı, 15-20 yaş olan katılımcıların mağaza atmosferine verdikleri önem puanından da yüksek bulunmuştur. Sonuç olarak, tüketicilerin yaşları ile mağaza atmosferine verdikleri önem puanları arasında fark bulunduğu için araştırmanın Hipotez 2'si kabul edilmiştir. Ayrıca katılımcıların mağaza atmosferine verdikleri önem puanı 
ortalamalarının eğitim durumu değişkenine göre anlamlı bir farklılık gösterip göstermediğini belirlemek amacıyla yapılan tek yönlü varyans analizi (Anova) sonucunda ise fark anlamlı bulunmuş ve Hipotez:3 kabul edilmiştir. Yapılan tek yönlü varyans analizine göre eğitim durumu lisansüstü olan katılımcıların mağaza atmosferine verdikleri önem puanı, eğitim durumu lise olan katılımcıların puanından yüksek bulunmuştur. Katılımcıların mağaza atmosferine verdikleri önem puanı ortalamalarının medeni durum değişkenine göre anlamlı bir farklılık gösterip göstermediğini belirlemek amacıyla yapılan ttesti sonucunda grup ortalamaları arasındaki fark istatistiksel açıdan anlamlı bulunmamıştır. $\mathrm{Bu}$ sebeple Hipotez 4 reddedilmiştir. Araştırmada, çalışmaya katılan aktif iş yaşamında bulunan katılımcılar ile mağaza atmosferine verdikleri önem puanı, araştırmaya katılan aktif iş yaşamında bulunmayan katılımcıların mağaza atmosferine verdikleri önem puanından yüksek bulunmuştur. Diğer bir deyişle, katılımcıların mağaza atmosferine verdikleri öneme yönelik tutum puanı ortalamalarının çalışma durum değişkenine göre anlamlı bir farklılık gösterip göstermediğini belirlemek amacıyla yapılan t-testi sonucunda grup ortalamaları arasındaki fark istatistiksel açıdan anlamlı bulunmuştur. Bu bağlamda Hipotez: 5 kabul edilmiştir. Ankete katılan katılımcıların mağaza atmosferine verdikleri öneme yönelik puanı ortalamalarının gelir durumu değişkenine göre anlamlı bir farklılık gösterip göstermediğini belirlemek amacıyla yapılan tek yönlü varyans analizi (Anova) sonucunda grup ortalamaları arasındaki fark istatistiksel açıdan anlamlıdır. Gelir durumu3.000-4.999TL olankatılımcların mağaza atmosferine verdikleri öneme yönelik puanı $(3,739 \pm 0,526)$, gelir durumu 1.000-2.999 TL olan katılımcıların puanından $(3,367 \pm 0,708)$ yüksek bulunmuştur. Bu bağlamda Hipotez 6 kabul edilmiştir. Katılımcıların demografik özellikleri ile mağaza atmosferine verilen önem arasında anlamlı bir farkın olup olmadığının araştırıldığı bu çalışmanın, ileride yapılacak çalışmalara yol göstereceği düşünülmektedir. Araştırmada mağaza atmosferinin önemi irdelenirken, kozmetik mağazası üzerinden incelenmiştir. Bu bağlamda ilerideki çalışmalar giyim, ayakkabı gibi farklı mağaza türleri üzerinden yapılabilir. Ayrıca ileride yapılacak çalışmalarda, mağaza atmosferinin faktörlerine koku, müzik, tat gibi yeni faktörler eklenebilir, farklı demografik özelliklere sahip bireyler üzerinde çalışmalar yapılabilir. Ayrıca çalışmanın markaların stratejilerini belirlemesinde yol gösterici olacağına da inanilmaktadır.

\section{Kaynakça}

Acar, E., \& Sönmez, H. (2015). Konjoint analizi ve genç kadın tüketicilerin hazır giyim mağaza tercihlerini etkileyen unsurların incelenmesi. The Journal of Academic Social Science, 3(12), 278-295.

Akyüz, İ. (2015). Farklı demografik özellikteki Tüketici gruplarına göre mobilya satış mağazası atmosferi oluşturma üzerine bir araştırma. Selçuk-Teknik Dergisi, 14 (2), 896-907.

Altuna, O. K. (2015). Duyusal markalama. M. Arslan (Ed.), Masamızda marka sohbetleri içinde (s.67-98). İstanbul:Beta Basım Yayım Dağıtım.

Arslan, B. (2016). Sanal mağaza atmosferi unsurlarının anlık satın almaya etkisi. Bitlis Eren Üniversitesi Sosyal Bilimler Enstitüsü Dergisi, 5 (1), 117-136.

Arslan, M. (2011). Mağazacılıkta atmosfer. 2. Baskı. İstanbul: Beta Basım Yayım Dağıtım. 
Aydın, K. (2013). Perakende yönetiminin temelleri. 4. Baskı. Ankara: Nobel Akademik Yayıncılık Eğitim Danışmanlık.

Batı, U. (2013). Markethink ya da farkethink. 2. Baskı. İstanbul: İyi Yayınlar.

Bayçu, S. (2016), Mağaza atmosferi (Ünite 1, 2, 6), 3. Baskı. M. Oyman (Ed.), T.C. Anadolu Üniversitesi Yayını No: 2465, Açıöğretim Fakültesi Yayını No:1436. Eskişehir:Anadolu Üniversitesi.

Bayraktar, A. (2011). Görsel mağazacılıkta vitrinlerin önemi. İstanbul:Beta Basım Yayım Dağıtım.

Bellizzi, J., \& Hite, R. (1992). Environmental color, consumer feelings, and purchase likelihood. Psychology \& Marketing. 9 (5), 347-363.

Berman, B., \& Evans, J. (1992). Retail management: a strategic approach. New York: Macmillan Publishing Company.

Childers, T., Carr, C., Peck, J. \& Carson, S. (2001). Hedonic and utilitarian motivations for online retail shopping behavior. Journal of Retailing. 77 (4), 511-535.

Demirci, F. (2000). Perakendecilikte mağaza düzenlemesi. İstanbul: Beta Basım Yayım Dağıtım.

Fettahlığlu, S. H. (2014).Tüketicilerin mağaza atmosferinden etkilenme düzeylerinin demografik faktörler açısından incelenmesi. Akademik Araştırmalar ve Çalışmalar Dergisi. 6(11), 27- 40 .

Gegez, E. (2013). Pazarlama araştırmaları. İstanbul: Beta Basım.

Inman, J. \& Winer, R. (1998). Where the rubber meets the road : a model of in store consumer decision making. Working Paper, Report No:98 Cambridge: Marketing Science Institute, pp.98-122.

İstanbul Alışveriş Caddeleri Raporu neler söylüyor?. (2017). Erişim: 02 Ocak 2019, https://gayrimenkulturkiye.com/2017/01/25/rapor-istanbul-ana-caddeleri-2017/

Kachaganova, E. (2008). Mağaza atmosferinin satın almaya etkisi ve departmanlı mağazada bir uygulama (Doktora tezi, Marmara Üniversitesi, İstanbul). Erişim adresi: http://tez2.yok.gov.tr/

Kozmetikte Tüketim Profili (2002), Capital Dergisi. https://www.capital.com.tr/isdunyasi/soylesiler/kozmetikte-tuketim-profili-490973 Erişim Tarihi: 14.01.2019.

Kurtuluş, K. (2010), Araştırma yöntemleri. İstanbul: Türkmen Kitabevi.

Küçükköylü, S. (2010), Perakendecilikte mağaza atmosferinin mă̆aza imajı oluşturmadaki önemi ve Konya ilinde bir araştırma. (Yüksek lisans tezi, Selçuk Üniversitesi, Konya).

Labrecque, L., \& Milne, G. (2012). Exciting red and competent blue: the importance of color in marketing. Journal of The Academy of Marketing Science. (40), 711-727. DOI 10.1007/s11747-010-0245-y

Levy, M., \& Weitz, B. (2001). Retailing management, 4th Edition, McGraw Hill, Irwin, New York: International Edition.

Linstrom, M. (2012), Brand washed. İstanbul: Optimist Yayınları. 
Madden, T., Hewett, K., \& Roth, M. (2000). Managing images in different cultures: a crossnational study of color meanings and preferences. Journal of International Marketing. 8 (4),90-107.

Martineau, P. (1958). The personality of the retail store. Harvard Business Review. 36 (1), 47-55.

Mcdonnell, J. (2007). Music, scent and time preferences for waiting lines. International Journal of Bank Marketing. 25 (4), 223-237.

Milliman, R. (1982). Using background music to affect the behavior of supermarket shoppers. The Journal of Marketing. 46 (3),86-91.

Mulhern, F. (1997). Retail marketing: from distribution to integration. International Journal of Research in Marketing. 14(2),103-124.

Naresh, M., \& Birks, D. (2000). Marketing research an applied approach. London: Prentice Hall.

Odabaşı, Y., \& Barış, G. (2006). Tüketici davranışı. 6. Baskı. İstanbul: MediaCat Yayınları.

Okay, A. (2013). Kurum kimliği. 7. Baskı. İstanbul: Derin Yayınları.

Özdamar, K. (2004), Paket programlar ile istatiksel veri analizi, 5. Baskı. Eskişehir: Kaan Kitabevi.

Pelsmacker, D., Geuens, M., \& Bergh, J. (2001). Marketing communications. London: Prentice Hai.

Rosenberg, J. (1995). Dictionary of retailing and merchandising. New York: John Wiley \& Son.

Tosun, N. (2017). Marka yönetimi. 3. Baskı. İstanbul: Beta Basım Yayım.

Tuğsal, T. (2014). Modern perakendecilik ve mağaza yönetimi. Ankara: Gazi Kitabevi.

Turley, L., \& Chebat, J. (2002). Linking retail strategy, atmospheric design and shopping behaviour. Journal of Marketing Management. 18 (1-2),125-144. DOI:

$10.1362 / 0267257022775891$

Vlahos, J. (2007). Scent and sensibility. Erişim: 01 Ocak, 2019. https://www.nytimes.com/2007/09/09/realestate/keymagazine/909SCENT-txt.html

Yalch, R. \& Spangenberg, E. (2000). The effects of music in a retail setting on real and perceived shopping times. Journal of Business Research. 49 (2), 139-147.

Yeniçeri, T. (2005).Mağaza imajı ve mağaza imajı boyutları arasındaki ilişkilerin yapısal eşitlik modeli ile incelenmesi. Yönetim Dergisi. 16 (52), 39-53.

Yüksekbilgili, Z. (2016). Hızlı moda tüketicilerinin mağaza atmosferine verdikleri önemin ölçülmesi İçin Bir ölçek geliştirme çalışması: Avrasya mağaza atmosfer ölçeği. Akademik Sosyal Araştırma Dergisi. 4 (30), 444-473. 